\title{
Monitoring serum CEA in women with primary breast tumours positive for oestrogen receptor and with spread to lymph nodes
}

\author{
JC VAN DER LINDEN, $†$ JPA BAAK, $\ddagger$ T POSTMA,$\dagger$ J LINDEMAN, $\dagger$ CJLM MEYER \\ From the †Department of Pathology, Stichting Samenwerking Delftse Ziekenhuizen, Delft, The Netherlands \\ and the $¥$ Department of Pathology, Free University Amsterdam, Amsterdam, The Netherlands
}

SUMMARY Serum carcinoembryonic antigen concentrations (serum CEA) in 80 patients with primary breast cancer were measured preoperatively, one month after operation, and thereafter serially every third month. These data were related to histological and morphometric features of the primary breast carcinoma and the lymph node metastases and to clinical follow up data.

Analysis of the serum CEA values showed significant correlations with size of tumour, the presence of lymph node metastases, oestrogen receptor, and occurrence of distant metastases. Furthermore, the results indicated that serial determination of serum CEA in the first two years after operation may be useful in monitoring for the occurrence of distant metastases in patients with metastatic spread to lymph nodes and with large $(\geqslant 2 \mathrm{~cm})$ primary breast tumours positive for oestrogen receptor. In agreement with other studies, however, it was found that the predictive value of serum CEA concentrations in general is weak and costs may prohibit the implementation of the routine assessment of CEA concentrations.

Determination of carcinoembryonic antigen (CEA) in the serum of patients with breast cancer has been the subject of many investigations, ${ }^{1-17}$ most of which had different aims, varying from defining CEA as a prognostic factor at or before operation ${ }^{101617}$ to serial estimations of serum CEA to monitor for metastatic disease or reaction to treatment. ${ }^{38}$

The results of these studies were rather negative as they showed that CEA is not a specific tumour marker for breast carcinoma and that high serum CEA concentrations at or before operation have no prognostic importance. Although studies showed that serial estimations of serum CEA were useful in monitoring patients operated on for breast cancer, the sensitivity for discovering recurrence was not very high (varying from 30 to $71 \%$ ). ${ }^{6}{ }^{13}$

It might be, however, that evaluation of serum CEA would be useful in a particular subgroup of patients. In this study, therefore, we investigated the relation of serial estimations of serum CEA concentrations to clinical follow up and to the histologi-

Accepted for publication 11 June 1985 cal and morphometric features of the primary tumour. The main purpose of our study was to find criteria for selecting patients who would benefit from the monitoring of serum CEA concentration.

\section{Material and methods}

PATIENTS AND CLINICAL DATA

All of the female patients $(n=80)$ who had undergone surgery for primary breast carcinoma without other overt diseases, who presented at the Reinier de Graaf Hospital, Delft, The Netherlands, from 1 January 1981 until 31 December 1982 were included in this study.

The mean age of the patients was 59.1 years (range 26-91 (SD) 13.8). We were able to assess the size of the tumour in 73 patients: the mean diameter was $2.5 \mathrm{~cm}$ (range $0.5-6.5 \mathrm{~cm}(1.4)$ ). In 70 patients lymph nodes were available for study. Forty $(51 \%)$ of these patients had lymph node metastases and 29 (36\%) did not. The mean duration of follow up was 36 months (minimum 25, maximum 49 months).

The data collected from the clinical records were: 
organs affected by metastases, date of appearance of distant metastases, type of treatment, and cause of death. All patients studied were examined every three months postoperatively during the first two years and every six months thereafter. At each control visit measurement of serum CEA formed part of the routine haematological, biochemical, and physical examinations. $X$ ray films of the thorax were obtained every six months, in addition to those made because of symptoms verbalised by the patient or physical findings, or both. Distant metastasis was diagnosed if a combination of clinical, radiographic, scintigraphic, and biochemical data (excluding CEA values) were conclusive, or if metastasis was diagnosed histologically. Both local and distant metastases were considered. Patients with local recurrence (in the skin, axilla, and mastectomy scar) and one patient with contralateral breast disease were separately considered in the study; histological examination did not determine whether this last patient had a second primary tumour or a metastasis.

\section{HISTOLOGICAL METHODS}

The size of the primary tumour was assessed on the excision specimen. The primary breast tumours and all the available lymph nodes were fixed in $5 \%$ buffered formalin and subsequently embedded in paraplast. From this material tissue sections $4 \mu \mathrm{m}$ thick were stained with haematoxylin and eosin. The condition of the lymph nodes and the following histological features of the primary carcinoma were assessed.

\section{HISTOLOGICAL TUMOUR TYPE}

All 80 cases of breast carcinoma were classified according to the World Health Organisation recommendations ${ }^{18}$ : ductal $(n=68)$; lobular $(n=$ $1)$; medullary $(n=4)$; and others $(n=7)$. Nuclear grading was performed according to Black et al. ${ }^{19}$ Histological grading was done according to Bloom and Richardson. ${ }^{20}$ Only ductal carcinomas were graded $(n=68)$.

\section{MORPHOMETRY}

Morphometry was performed, as described by Baak et al, ${ }^{21-23}$ on the stained sections from both the primary tumour and, if present, the lymph node metastases. The following morphometric features were assessed: mitotic activity index; cellularity index; and several nuclear features: perimeter, area, shortest and longest axis, axes ratio, and shape factor as $(4 \pi \times$ area $) /$ perimeter $^{2}$.

\section{OESTROGEN RECEPTOR CONTENT}

The oestrogen receptor content of the primary breast tumour was determined by biochemical assay as described by the EORTC breast cancer cooperative group. ${ }^{24}$ According to this procedure values of more than $11000 \mathrm{fmol}$ bound protein oestradiol were classified as positive. Values were regarded as negative if less than $9000 \mathrm{fmol}$ oestradiol $/ \mathrm{g}$ protein was found: sufficient frozen material was available from only 51 patients.

\section{CARCINOEMBR YONIC ANTIGEN}

The CEA enzyme immunoassay applied was a direct radioimmunoassay (Abbott CEA-EIA monoclonal (mouse), Abbott Diagnostics, United States). According to the manufacturer, this kit contains a mixture of five monoclonal antibodies reactive with all known immunoreactive elements of CEA. The serum CEA concentrations (in serum samples of $100 \mu \mathrm{l})$ were estimated preoperatively; one month after operation; and successively every third month. Likewise, the highest serum carcinoembryonic antigen concentrations (CEA-H) found in each patient during the follow up period were collated and analysed.

\section{ANALYSIS}

Statistical analysis of the data was performed using $\chi^{2}$ contingency tables, linear regression, and the Wilcoxon rank sum test. P values of 0.05 or less were regarded as significant. Special attention was paid to the cut off point of serum CEA concentrations. Different thresholds were separately investigated $(2 \cdot 5,5,10$, and $20 \mathrm{ng} / \mathrm{ml}$, respectively) and 5 $\mathrm{ng} / \mathrm{ml}$ was found to be the optimal cut off point for monitoring. In subsequent analyses, therefore, serum CEA concentrations $\leqslant 5 \mathrm{ng} / \mathrm{ml}$ were regarded as negative $(-)$, concentrations $>5$ and $\leqslant 10 \mathrm{ng} / \mathrm{ml}$ as positive $(+)$, and concentrations $>10 \mathrm{ng} / \mathrm{ml}$ as strongly positive $(++)$.

\section{Results}

\section{CEA AND INVESTIGATED FEATURES}

Tables 1 and 2 show the data from serum CEA concentrations (those measured preoperatively and one month after operation, and the highest values) and Table 1 Distribution of serum carcinoembryonic antigen (serum CEA) preoperatively and one month after operation, and distribution of highest value in each patient

\begin{tabular}{lccc}
\hline & $\begin{array}{l}\text { Preoperative } \\
\text { value }\end{array}$ & $\begin{array}{l}\text { Postoperative } \\
\text { value } \\
\text { (one month) }\end{array}$ & $\begin{array}{l}\text { Highest } \\
\text { value }\end{array}$ \\
\hline $\begin{array}{l}\text { Serum CEA }>10 \mathrm{ng} / \mathrm{ml} \\
\text { Serum CEA }>5,\end{array}$ & 3 & 13 \\
$\begin{array}{l}\leqslant 10 \mathrm{ng} / \mathrm{ml} \\
\text { Serum CEA } \leqslant 5 \mathrm{ng} / \mathrm{ml} 68\end{array}$ & 8 & 10 \\
\hline Total No of patients 80 & 74 & 57 \\
\hline
\end{tabular}


Table 2 Distributions of serum carcinoembryonic antigen (serum CEA) preoperatively and one month postoperatively and of highest concentration in each patient in relation to lymph node metastases, tumour size, and oestrogen receptor states

\begin{tabular}{|c|c|c|c|c|c|c|c|c|}
\hline & \multicolumn{6}{|c|}{ Serum CEA } & \multirow{2}{*}{\multicolumn{2}{|c|}{ Total No of patients }} \\
\hline & \multicolumn{2}{|c|}{$>10 \mathrm{ng} / \mathrm{ml}$} & \multicolumn{2}{|c|}{$>5, \leqslant 10 \mathrm{ng} / \mathrm{ml}$} & \multicolumn{2}{|l|}{$\leqslant 5 \mathrm{ng} / \mathrm{ml}$} & & \\
\hline & Negative & Positive & Negative & Positive & Negative & Positive & Negative & Positive \\
\hline $\begin{array}{l}\text { Lymph nodes: } \\
\text { Preoperative value* } \\
\text { Postoperative value } \\
\text { Highest value† } \\
\text { Tumour sizel: }\end{array}$ & $\begin{array}{l}0 \\
0 \\
1\end{array}$ & $\begin{array}{l}3 \\
2 \\
9\end{array}$ & $\begin{array}{l}1 \\
0 \\
2\end{array}$ & $\begin{array}{l}5 \\
1 \\
5\end{array}$ & $\begin{array}{l}28 \\
29 \\
26\end{array}$ & $\left.\begin{array}{l}33 \\
38 \\
27\end{array}\right\}$ & 29 & 41 \\
\hline $\begin{array}{l}\text { Preoperative value }{ }^{* *} \ddagger \\
\text { Postoperative value } \\
\text { Highest value } \\
\text { Oestrogen receptorf: }\end{array}$ & $\begin{array}{l}0 \\
0 \\
1\end{array}$ & $\begin{array}{l}4 \\
3 \\
9\end{array}$ & $\begin{array}{l}\mathbf{0} \\
0 \\
\mathbf{0}\end{array}$ & $\begin{array}{r}7 \\
2 \\
10\end{array}$ & $\begin{array}{l}27 \\
27 \\
26\end{array}$ & $\left.\begin{array}{l}35 \\
41 \\
27\end{array}\right\}$ & 27 & 46 \\
\hline $\begin{array}{l}\text { Yreoperative value } \\
\text { Postoperative value§ } \\
\text { Highest value }\end{array}$ & $\begin{array}{l}0 \\
0 \\
0\end{array}$ & $\begin{array}{l}4 \\
3 \\
6\end{array}$ & $\begin{array}{l}0 \\
0 \\
0\end{array}$ & $\begin{array}{l}3 \\
0 \\
6\end{array}$ & $\begin{array}{l}11 \\
11 \\
11\end{array}$ & $\left.\begin{array}{l}33 \\
37 \\
28\end{array}\right\}$ & 11 & 40 \\
\hline
\end{tabular}

*Lymph node positive $v$ negative: $\mathrm{p}<0.05$, Wilcoxon.

†Lymph node positive $v$ negative: $\mathrm{p}<0.005$, Wilcoxon.

Tumour size: negative $<2 \mathrm{~cm}$, positive $\geqslant 2 \mathrm{~cm}$.

**Tumour size: positive $v$ negative; $p<0.05$, Wilcoxon.

$\ddagger$ Linear regression: preoperative value $v$ tumour size $\mathrm{p}<0.005, \mathrm{r}=0.34$.

ףOestrogen receptor: negative $<9 \mathrm{fmol} / \mathrm{mg}$, positive $\geqslant 11 \mathrm{fmol} / \mathrm{mg}$.

§Postoperative value $v$ oestrogen receptor state; $\mathrm{p}<0.01, \mathrm{r}=0.37$.

the significantly correlated features-that is, size of tumour and oestrogen receptor content, and presence or absence of lymph node metastases. In six of 12 patients the serum CEA value decreased below 5 $\mathrm{ng} / \mathrm{ml}$ during the first month after operation.

Fourteen of the 41 patients $(34 \%)$ with positive lymph nodes and only three of the 29 patients $(10 \%)$ with negative lymph nodes achieved serum CEA concentrations $>5 \mathrm{ng} / \mathrm{ml}$ (Wilcoxon test, $\mathrm{p}<$ 0.01 ; Table 2). Nineteen of the 46 patients $(41 \%)$ with a tumour $\geqslant 2 \mathrm{~cm}$ had, on more than one occa-

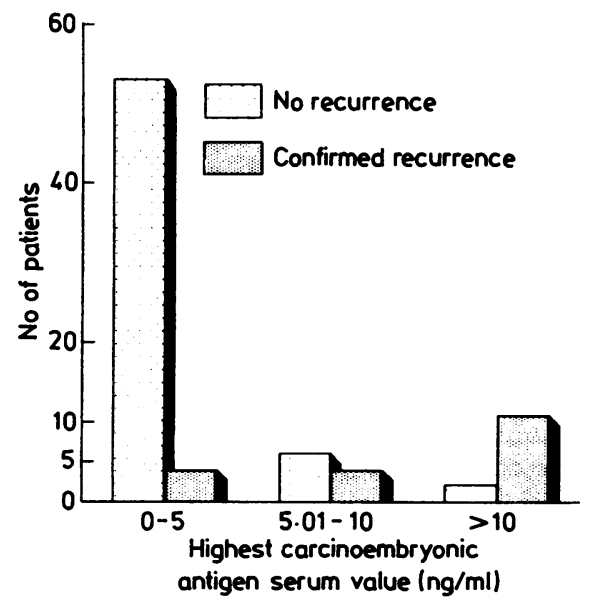

Fig. 1 Histogram of highest serum CEA values in patients with and without recurrence. sion, positive $(+/++)$ serum CEA values compared with only one patient of the $27(4 \%)$ with a tumour $<2 \mathrm{~cm}$ (Wilcoxon test, $\mathrm{p}<0.05$; Table 2).

Analysis by linear regression of the data on oestrogen receptor and serum CEA concentrations showed that a significant correlation between these features was present for only the period one month to 18 months after operation (data not shown). Table 2 shows that only patients positive for oestrogen receptor (12 of the $40(30 \%)$ ) reach serum

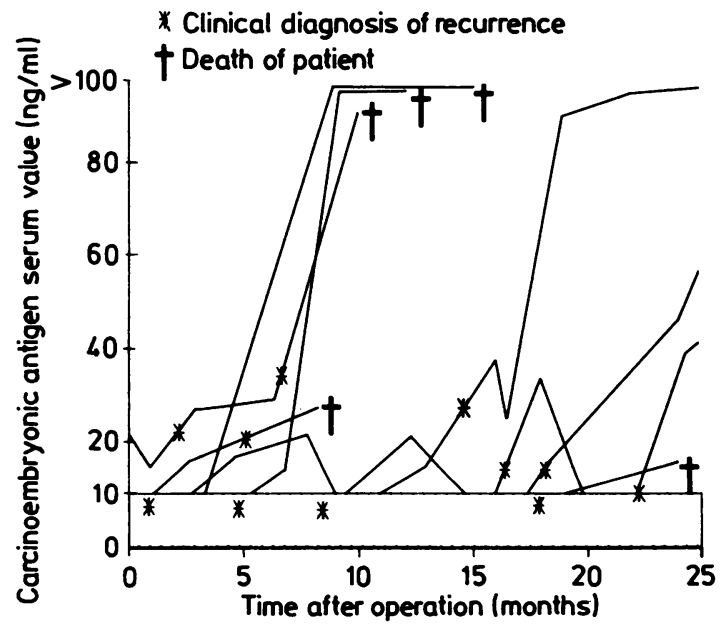

Fig. 2 Diagram of patients with recurrence and increased serum CEA values. Only 11 patients with serum $C E A$ values $>10 \mathrm{ng} / \mathrm{ml}$ are shown. Four patients also had increased serum CEA values between 5-10 $\mathrm{ng} / \mathrm{ml}$. 
Table 3 Recurrence related to highest serum carcinoembryonic concentrations (serum CEA) and whether absence or presence of lymph node metastases, tumour size, and oestrogen receptor contents were positive or negative

\begin{tabular}{|c|c|c|c|c|c|}
\hline & \multicolumn{2}{|c|}{ Serum $C E A<5 \mathrm{ng} / \mathrm{ml}$} & \multicolumn{2}{|c|}{ Serum $C E A \geqslant 5 \mathrm{ng} / \mathrm{ml}$} & \multirow[t]{2}{*}{ Total } \\
\hline & Negative & Positive & Negative & Positive & \\
\hline \multicolumn{6}{|c|}{ Lymph node* } \\
\hline Recurrence & 0 & 4 & 1 & 10 & 15 \\
\hline No recurrence & 26 & 23 & 2 & 4 & 55 \\
\hline \multicolumn{6}{|c|}{ Tumour size $\ddagger$} \\
\hline Recurrence & 0 & Thi & 1 & 11 & 16 \\
\hline No recurrence & 26 & 23 & 0 & 8 & 57 \\
\hline Total & 26 & 27 & 1 & 19 & 73 \\
\hline \multicolumn{6}{|c|}{ Oestrogen receptor content $\$ \|$} \\
\hline Recurrence & 3 & 0 & 0 & 6 & 9 \\
\hline No recurrence & 8 & 28 & 0 & 6 & 42 \\
\hline Total & 11 & 28 & 0 & 12 & 51 \\
\hline
\end{tabular}

${ }^{*} \chi^{2}=28 \cdot 8, v=3, \mathrm{p}<0.001$.

+ Tumour size: negative $<2 \mathrm{~cm}$, positive $\geqslant 2 \mathrm{~cm}$.

$\neq x^{2}=26.0, v=3, p<0.001$.

§Oestrogen receptor content: negative $<9 \mathrm{fmol} / \mathrm{ng}$, positive $\geqslant 11 \mathrm{fmol} / \mathrm{ng}$.

$x^{2}=15 \cdot 3, v=2, p<0.005$.

CEA positivity $(+/++)$ during the follow up period.

No significant correlations were found between the serum CEA values and the age of the patient, the histological grade, the nuclear grade the histological type or the morphometric features of the primary carcinoma.

\section{CEA AND RECURRENCE}

Analysis of the clinical data showed a clear correlation between an increase in serum CEA concentrations and the recurrence of the disease (locally or with distant metastases, or both) (Wilcoxon: $p<$ 0.001 , Fig. 1). During the follow up period recurrences were diagnosed clinically in 19 patients (24\%) (three patients had local recurrence). Fifteen of these $(79 \%)$ had serum CEA values $>5 \mathrm{ng} / \mathrm{ml}$ (Fig. 1).

Analysis of the 15 patients with serum CEA concentrations $>5 \mathrm{ng} / \mathrm{ml}$ showed that seven had shown an increase in concentration more than one month before the clinical diagnosis of the recurrence. In four patients it was not completely clear from the clinical data whether the increase in concentration had preceded or succeeded the clinical diagnosis. In four other patients the increase occurred more than one month after the clinical diagnosis of the recurrence (Fig. 2).

\section{CEA AND ASSOCIATED FEATURES RELATED TO RECURRENCE}

To find a group of patients who might benefit from serial measurements of serum. CEA several analyses were performed, using tumour recurrence as a dependent variable. The highest serum CEA values were combined with one of the three features that proved to be significantly correlated with the serum
CEA values-namely, size of tumour, oestrogen receptor contents, and presence or absence of lymph node metastases. Table 3 shows the data on these combinations. In the analysis $\left(\chi^{2}\right)$ highest CEA values of more than $5 \mathrm{ng} / \mathrm{ml}(\mathrm{CEA}-\mathrm{H}+)$ were compared with those $5 \leqslant \mathrm{ng} / \mathrm{ml}(\mathrm{CEA}-\mathrm{H}-)$. The combination of $(-v+)$ when related to highest CEA value and presence or absence of lymph node metastases was significant $\left(\chi^{2}=28.8 v=3, p<0.001\right.$, Table 3). Ten of 14 patients (71\%) who were CEA-H positive and lymph node positive developed distant metastases whereas none of the 26 patients who were CEA-H negative/lymph node negative did. Thus CEA-H positive/lymph node positive patients had significantly more recurrences than those who were negative. The combination of CEA-H and size of tumour was significant $\left(\chi^{2}=\right.$ $26.0, v=3, p<0.001$; Table 3) when related to tumour recurrence. None of the $26 \mathrm{CEA}-\mathrm{H}$ negative patients with a tumour $<2 \mathrm{~cm}$ had recurrence. Eleven out of $19(58 \%)$ of the CEA-H positive group with a tumour $\geqslant 2 \mathrm{~cm}$ developed recurrent disease.

Table 3 shows the significant correlation between the development of recurrences and the combination of CEA-H level and oestrogen receptor state $\left(\chi^{2}=15 \cdot 3, v=2, \mathrm{p}<0 \cdot 001\right)$. Although this correlation when compared with the above correlations was not that significant, it was an interesting factor, for six patients of 12 who were CEA-H positive/ oestrogen receptor positive had tumour recurrence.

\section{Discussion}

A significant correlation was found between the highest serum CEA concentrations and recurrence of the disease (Fig. 1). This correlation has also been 
found in other studies. ${ }^{3691213}$ In our study 15 of 19 (79\%) patients with serum CEA values $>5 \mathrm{ng} / \mathrm{ml}$ developed recurrences. This percentage is somewhat higher than that described in published reports (range $30-71 \%$ ). This is obviously because most of the studies took $10 \mathrm{ng} / \mathrm{ml}$ as the cut off point. If this threshold had been adopted in the present study the sensitivity would have fallen to $57 \%$ (11/19), which is more in line with other studies. With $5 \mathrm{ng} / \mathrm{ml}$ as a threshold 23 patients had concentrations above that value more than two months after the operation and $13 \mathrm{had}$ concentrations above $10 \mathrm{ng} / \mathrm{ml}$. Therefore, 13 patients had values between 5 and $10 \mathrm{ng} / \mathrm{ml}$. Of these, four developed distant metastasis (and no local recurrence). This high percentage clearly supports the choice of 5 instead of $10 \mathrm{ng} / \mathrm{ml}$ as the threshold.

Of the four patients with metastases and without a serum CEA value $>5 \mathrm{ng} / \mathrm{ml}$, three had local recurrence. This is in agreement with the findings of Haagensen et $\mathrm{l}^{7}$ and Lee. ${ }^{9}$ Apparently, local metastases can be easily missed when monitoring serum CEA for recurrence, but physical examination should easily detect these recurrences.

Eight patients had increased serum CEA concentrations without confirmed metastatic disease (Table 1). Two of these had values above $10 \mathrm{ng} / \mathrm{ml}$. One patient developed carcinoma in the contralateral breast. This was not regarded as a metastasis, although the tumour was detected by an increase in serum CEA. The other patient had a large $(>6 \mathrm{~cm})$ breast carcinoma (without lymph node metastases) at presentation. The high serum CEA value decreased and became normal within two months after the operation, and no distant metastases were found during the follow up period. In four of the patients with serum CEA values $>5 \mathrm{ng} / \mathrm{ml}$ but $\leqslant 10$ $\mathrm{ng} / \mathrm{ml}$ the values also decreased below $2.5 \mathrm{ng} / \mathrm{ml}$ in the first three postoperative months.

This finding may have been due to the fact that it takes time for CEA to be degraded. ${ }^{15}$ Our results support the theory that estimations of serum CEA should be started two or three months after operation to remove primary breast carcinoma and that 5 $\mathrm{ng} / \mathrm{ml}$ is a reasonable threshold value. In this study only two of 65 patients (31\%) gave false positive results. This is lower than the value found by Lee, who found falsely increased serum CEA concentrations in his patients. ${ }^{\prime}$

Meyers et al found a correlation between serum CEA values established within three months after operation and the presence of lymph node metastases. "In that study a quarter of the patients with spread to lymph nodes were also positive for serum CEA compared with $13.9 \%$ of the patients without such spread. Values $\geqslant 4 \mathrm{ng} / \mathrm{ml}$ were regarded as positive. In our study this difference was also found between patients with positive lymph nodes and those with negative lymph nodes, and the preoperative serum CEA values $(19.5 \%$ compared with $3.4 \%$; Table 2). In addition, Meyers and other workers found correlations between larger primary tumours and higher serum CEA values. ${ }^{41} 1^{13}$ In our study this correlation was found, by linear regression analysis, in the serum CEA values established preoperatively (Table 2 ).

The significant correlations found between the serum CEA values established in a short period (three months) after the operation and the size of tumour and presence of lymph node metastases are, in our opinion, due to tumour load. Therefore, no conclusions can be drawn from these results about monitoring patients with breast cancer for recurrence. During the follow up period, however, larger primary tumours with spread to lymph nodes had significantly higher serum CEA values than their smaller, lymph node negative counterparts (Table 2). This is in keeping with the belief that patients with larger primary tumours and spread to lymph nodes are more likely to develop metastases.

In this study not one patient with an oestrogen receptor negative tumour had a serum CEA value $>5 \mathrm{ng} / \mathrm{ml}$. This is strange because oestrogen receptor negative tumours tend to have a worse prognosis. Although the number of patients was small ( $n$ $=51$ ) and further investigation is required, Table 3 shows that all the patients with a recurrence were either oestrogen receptor negative and CEA negative or oestrogen receptor positive and CEA positive. By monitoring serum CEA in patients positive for oestrogen receptor recurrence can be detected in this group of patients with an apparently better prognosis.

Our results show that the appearance of distant metastases in patients with primary breast cancer can be monitored in the first two years after operation by serial estimations of serum CEA only in patients with tumours $\geqslant 2 \mathrm{~cm}$ that are positive for oestrogen receptor who have spread to the lymph nodes.

Supported in part by grant $28-735$ from Praeventiefonds.

\section{References}

' Bezwoda W, Derman D, Bothwell T, Levin PT, Moor N. Significance of serum concentrations of carcinoembryonic antigen, ferritin, and calcitonin in breast cancer. Cancer 1981;48:1623-8.

${ }^{2}$ Chatal JF, Chupin F, Ricolleau G, et al. Use of serial carcinoembryonic antigen assays in detecting relapses in breast cancer 
involving high risk of metastasis. European Journal of Cancer 1981;17:233-8.

${ }^{3}$ Falkson HC, Falkson G, Portugal MA, Watt van der JJ, Schoeman HS. Carcinoembryonic antigen as a marker in patients with breast cancer receiving postsurgical adjuvant chemotherapy. Cancer 1982;49:1859-65.

${ }^{4}$ Falkson HC, Watt van der JJ, Portugal MA, Pitout MJ, Falkson G. Carcinoembryonic antigen in patients with breast cancer Cancer 1978; 42:1308-13.

s Falkson HC, Watt van der JJ, Portugal MA, Schoeman HS, Falkson G. Role of plasma carcinoembryonic antigen in evaluating patients with breast cancer treated with adjuvant chemotherapy. Cancer Treat Rep 1979;63:1303-9.

${ }^{6}$ Haagensen DE, Kister SJ, Panick J, Giannola J, Hansen HJ, Wells SA. Evaluation of carcinoembryonic antigen as a plasma monitor for human breast cancer. Cancer 1978;42:1512-9.

' Haagensen DE, Kister SJ, Vandevoorde JP, et al. Comparative evaluation of carcinoembryonic antigen and gross cystic disease fluid protein as plasma markers for human breast cancer. Cancer 1978; 42:1646-52.

${ }^{8}$ Jong-Bakker M, Hart AAM, Persijn JP, Cleton FJ. Prognostic significance of CEA in breast cancer: a statistical study. Eur J Cancer Res Clin Oncol 1981;17:1307-13.

${ }^{9}$ Lee M. Carcinoembryonic antigen as a monitor of recurrent breast cancer. J Surg Oncol 1982;20:109-14.

${ }^{10}$ Mansour GE, Hastert M, Park CH, Koelher KA, Petrelli M. Tissue and plasma carcinoembryonic antigen in early breast cancer. Cancer 1983;51:1243-8.

" Meyers RE, Sutherland DJ, Meakin JW, Kellen JA, Malkin DG, Malkin A. Carcinoembryonic antigen in breast cancer. Cancer 1978; 42: 1520-6.

${ }^{12}$ Neville AM, Patel S, Laurence DJR, Cooper EH, Turberville C, Coombes RC. The monitoring role of plasma CEA alone in association with other tumor markers in colorectal and mammary carcinoma. Cancer 1978;42:1448-51.

${ }^{13}$ Tormey DC, Waalkes TP, Snyder JJ, Simon RM. Biological markers in breast carcinoma. III. Clinical correlations with carcinoembryonic antigen. Cancer 1977;35:2397-404.
14 Tormey DC, Waalkes TP, Ahmann D, et al. Biological markers in breast cancer. I. Incidence of abnormalities of CEA, HCG, three polyamines and three minor nucleosides. Cancer 1975; 35: 1095-100.

is Waalkes TP, Enterline JP, Shaper JH, Abeloff MD, Ettinger DS Biological markers in breast cancer. Cancer 1984;53:630-43.

${ }^{16}$ Wang DY, Bulbrook RD, Hayward JL, Hendrick JC, Franchimont P. Relation between plasma carcinoembryonic antigen and prognosis in women with breast cancer. European Journal of Cancer 1975;11:615-8.

17 Wharen B, Lidbrink E, Wallgren A, Eneroth P, Zajicek J. Carcinoembryonic antigen and other tumor markers in tissue and serum or plasma of patients with primary mammary carcinoma. Cancer 1978;42:1870-8.

${ }^{18}$ Azzopardi JG, Chepick OF, Hartmann WH, et al. The WHO histological typing of breast tumors. 2nd ed. Am J Clin Pathol 1982; 78:806-16.

${ }^{19}$ Black MM, Barclay THC, Hankley BF. Prognosis in breast cancer utilizing histologic characteristics of the primary tumor. Cancer 1975;36: 2048-55.

${ }^{20}$ Bloom HJG, Richardson WW. Histological grading and prognosis in breast cancer. Br J Cancer 1957;11:359-77.

${ }^{21}$ Baak JPA, Persijn JP. In search of the best qualitative microscopical or morphometrical predictor of estrogen receptor in breast cancer. Pathol Res Pract 1984; 187:307-14.

${ }^{22}$ Baak JPA, Snoo-Nieuwlaat de AJE, Graef de S, Makkink B, Boon M. Prognostic indicators in breast cancermorphometric methods. Histopathology 1982;6:327-39.

${ }^{23}$ Baak JPA, Oort J. A manual of morphometry in diagnostic pathology. Berlin: Springer Verlag, 1983.

${ }^{24}$ EORTC Breast Cancer Cooperative Group. Revision for the assessment of hormone receptors in human breast cancer. European Journal of Cancer 1980;16:1513-5.

Requests for reprints to: Dr JC van der Linden, Department of Pathology, Free University Amsterdam, de Boelelaan 1117, 1007 MB Amsterdam, The Netherlands. 